\title{
PENGARUH PEMBERIAN DAPHNIA TERHADAP KELULUSHIDUPAN DAN PERTUMBUHAN LARVA LOBSTER AIR TAWAR (Cherax quadricarinatus)
}

\author{
The Influence of Daphnia Distribution to Survival Rate \\ and Growth of Fresh Water Crayfish Larvae (Cherax quadricarinatus)
}

Ernawati, Rekna Wahyuni

Faculty of Agriculture, Yudharta University, Pasuruan, 67162, East Java, Indonesia

\begin{abstract}
ABSTRAK
Penelitian ini dimaksudkan untuk memberikan alternatif pakan alami bagi larva lobster air tawar dan diharapkan dapat memberikan informasi bagi peneliti dan masyarakat tentang pengaruh pemberian daphnia terhadap kelulushidupan dan pertumbuhan larva lobster air tawar, sehingga dapat merangsang tumbuhnya usaha budidaya hasil perikanan yang dapat berpeluang untuk menjadi komoditas ekspor unggulan. Berdasarkan hasil penelitian diperoleh nilai kelulushidupan (SR) larva lobster air tawar selama 42 hari masa pemeliharaan yaitu antara $86,67 \%-90 \%$, berat rata-rata mengalami peningkatan, laju pertumbuhan sesaat (SGR) tidak berpengaruh nyata, sedangkan rasio konversi pakan terbaik adalah perlakuan penambahan daphnia 14\% dari berat tubuh. Hasil pengukuran kualitas air pada kisaran suhu 18,33-19,88 OC, oksigen terlarut (DO) 4,73-4,84 mg/l, dan pH 7,12-7,30, sehingga masih layak untuk hidup dan tumbuh larva lobster air tawar.
\end{abstract}

Kata kunci : Daphnia, Lobster air tawar, pakan alami

\begin{abstract}
This research is meant to provide an alternative natural food for the larvae of freshwater crayfish and is expected to provide information to researchers and the public about the influence of Daphnia on survival rate and growth of larvae of freshwater crayfish, which can stimulate the growth of the cultivation of fish which can be likely to become commodity exports seed. The result showed survival rate (SR) freshwater lobster seed for 42 days maintenance period is between $86.67 \%-90 \%$, average weight increased, specific growth rate (SGR) had no significant effect, whereas the best feed conversion ratio Daphnia is the addition of treatment $14 \%$ of the body weight. Results of water quality measurements in the temperature range from 18.33 to 19.88 OC, dissolved oxygen (DO) from 4.73 to $4.84 \mathrm{mg} / \mathrm{l}$, and $\mathrm{pH} 7.12$ to 7.30, so it is still worth it to live and grow freshwater crayfish larvae.
\end{abstract}

\section{Key words : Daphnia. Fresh Water Crayfish, Natural feed}

\section{PENDAHULUAN}

Lobster air tawar (Cherax quadricarinatus) merupakan salah satu komoditi perikanan yang mempunyai bentuk tubuh yang unik dan juga memiliki warna khas dan beragam. Lobster yang dikenal oleh masyarakat selama ini adalah udang yang berasal dari tangkapan di laut dan belum bisa 
dibudidayakan. Sedangkan lobster air tawar sudah bisa dibudidayakan baik di akuarium maupun di kolam dan tidak dibutuhkan lahan yang luas (Anonymous, 2000). Menurut Iskandar (2003), hidangan lobster air tawar digemari karena dagingnya yang padat, pejal, empuk dan rasanya cukup gurih, terutama jika dibandingkan dengan lobster air laut atau jenis udang lainnya. Lobster air tawar juga memiliki kandungan gizi yang cukup tinggi terutama protein.

Sebenarnya permintaan pasar terutama pasar ekspor terhadap lobster air tawar cukup tinggi. Sejumlah negara telah meminta lobster air tawar, baik dalam keadaan hidup maupun beku. Jepang merupakan potensi pasar yang paling besar di Asia. Selain Jepang, negara Asia lainnya seperti Malaysia, Hongkong, Cina, Taiwan, Korea dan Singapura juga mengimpor lobster. Negara lain seperti Amerika Serikat, Kanada, Perancis, Belanda, Jerman, Belgia, Selandia Baru dan Australia juga menggemari lobster air tawar sebagai makanan favorit. Sedangkan pasar lobster dalam negeri seperti Jakarta, Surabaya dan Bali juga cukup ramai (Wiyanto dan Hartono, 2003).

Masa larva, terutama setelah melepaskan diri dari induknya, merupakan salah satu masa yang kritis dari seluruh siklus hidup lobster air tawar selain masa moulting. (Anonymous, 2005; Jacinto, 2003). Menurut Djajasewaka (1985), untuk melewati masa kritis tersebut, hal penting yang harus diperhatikan adalah pemberian pakan tambahan. Pakan tambahan bisa berupa pelet dan pakan alami.

Daphnia merupakan alternatif pakan alami yang merupakan jenis zooplankton. Pakan alami ini mempunyai beberapa kelebihan karena ukurannya relatif kecil dan sesuai dengan bukaan mulut larva / benih ikan, nilai nutisinya tinggi, mudah dibudidayakan, gerakannya dapat merangsang ikan untuk memangsanya, dapat berkembang biak dengan cepat sehingga ketersediaannya dapat terjamin, dan biaya pembudidayaannya relatif murah (Mujiman, 2000).

Tujuan dari penelitian ini adalah untuk mengetahui pengaruh pemberian daphnia terhadap kelulus hidupan dan pertumbuhan larva lobster air tawar selama masa pemeliharaan.

\section{Bahan dan Metode \\ Bahan}

Bahan yang dipakai adalah larva lobster air tawar (Cherax quadricarinatus) berumur 1 hari, berasal dari pembudidaya lobster di Malang Jawa Timur dan Daphnia sp yang diperoleh dengan cara mendapatkannya di Balai Benih Ikan Punten Batu.

\section{Alat}

Peralatan yang dipakai untuk penelitian ini meliputi akuarium, perangkat aerator, $\mathrm{pH}$ meter, oksimeter, timbangan analitik, pipa paralon dan selang penyipon.

\section{METODE PENELITIAN}

Metode yang digunakan adalah metode eksperimen, yaitu serangkaian percobaan untuk melihat suatu hasil (Amirin, 1990; Surachmad, 1989). Parameter utama yang diukur adalah kelulushidupan (SR) dan laju pertumbuhan (SGR) serta tingkat konversi pakan (FCR). Sedangkan parameter penunjang adalah kualitas air media meliputi suhu, oksigen terlarut dan $\mathrm{pH}$. Kualitas air diukur setiap hari sebanyak 2 (dua) kali pada pagi dan sore hari. 
Rancangan percobaan yang digunakan adalah Rancangan Acak Lengkap (RAL).

$\mathrm{A}=$ Pemberian daphnia dengan dosis $14 \%$ dari berat tubuh

$\mathrm{B}=$ Pemberian daphnia dengan dosis $16 \%$ dari berat tubuh

$\mathrm{C}=$ Pemberian daphnia dengan dosis $18 \%$ dari berat tubuh

$\mathrm{D}=$ Pemberian daphnia dengan dosis $20 \%$ dari berat tubuh

\section{Pelaksanaan Penelitian}

- persiapan meliputi : persiapan alat, pakan dan benih larva.

- Pengisian akuarium sebanyak perlakuan, masing-masing akuarium diisi 10 ekor larva

- Pemberian Daphnia 2x sehari pada pagi dan sore hari sesuai dosis perlakuan dengan ketentuan perbandingan $40 \%$ pagi dan $60 \%$ sore.

- Pengukuran kualitas air : meliputi suhu, DO, dan $\mathrm{pH}$ setiap hari pada pagi dan sore hari.

- Pengamatan 7 hari sekali meliputi :

\section{a. Tingkat Kelulushidupan / Survival} Rate (SR) (Heinsbroek, 1989)

Kelangsungan hidup dapat dihitung dengan rumus $\mathrm{SR}=\mathrm{Nt} \times 100 \%$

\section{No}

Dimana : $\quad$ SR = Kelulushidupan larva lobster air tawar (\%)

$\mathrm{Nt}=$ Jumlah larva yang hidup pada akhir penelitian (individu)

No $=$ Jumlah larva yang hidup pada awal penelitian (individu)

\section{b. Laju pertumbuhan Sesaat / Specific Growth Rate (SGR) (Heinsbroek, 1989)}

Laju pertumbuhan sesaat dihitung berdasarkan :

SGR $=\underline{\ln W t-\ln W o} \times 100 \%$

dimana SGR = laju pertumbuhan sesaat (\% BW / hari)

$\mathrm{Wt}=$ Berat rata-rata individu pada akhir penelitian (gr)

Wo $=$ Berat rata-rata individu pada awal penelitian (gr)

$$
\mathrm{t}=\text { Lama penelitian (hari) }
$$

\section{c. Rasio Konversi Pakan (Feed Conversion Ratio / FCR) (Heinsbroek, 1989)}

$$
\mathrm{FCR}=\frac{\mathrm{Fx} \text { BKf }}{W t-W o}
$$

Dimana $\mathrm{F} \quad=$ Jumlah pakan yang diberikan

Wt $=$ Berat rata-rata

individu pada waktu tertentu

Wo = Berat rata-rata individu awal penelitian (gr)

$\mathrm{BKf}=$ Berat kering makanan

\section{Analisis Data}

Data yang diperoleh selama penelitian dianalisis secara statistik dengan menggunakan analisis keragaman atau uji F (tabel sidik ragam selang kepercayaan 95\% dan 99\%). Apabila hasil tabel sidik ragam memberikan hasil berbeda nyata atau berbeda sangat nyata, maka dilanjutkan dengan uji BNT (Uji Beda Nyata Terkecil).

\section{HASIL DAN PEMBAHASAN}

Tingkat kelulushidupan (Survival Rate / SR)

Tingkat kelangsungan hidup lobster air tawar selama penelitian ditampilkan pada Gambar 1. 


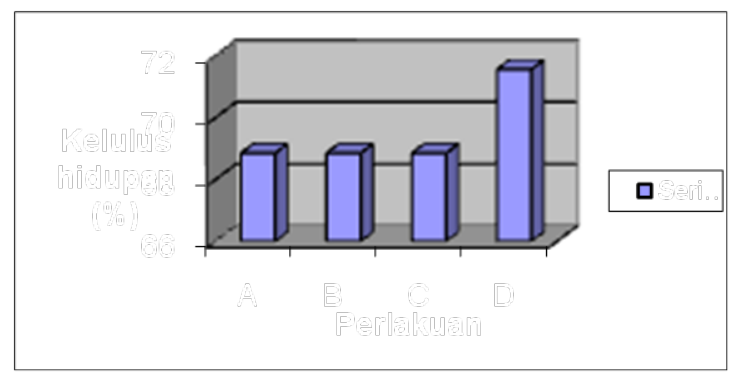

Gambar 1. Grafik kelulushidupan (SR) larva lobster air tawar (Cherax quadricarinatus) selama penelitian

Pada Gambar 1, perlakuan pemberian daphnia dengan dosis 20\% dari berat tubuh (D) memberikan kelulushidupan yang tertinggi dibandingkan yang lain. Hal ini berhubungan dengan pemberian pakan yang cukup sehingga mengurangi sifat kanibalisme pada lobster air tawar. Kematian yang terjadi selama penelitian dikarenakan beberapa hal. Menurut Patasik (2004), lobster air tawar (Cherax quadricarinatus) memiliki sifat kanibal terutama pada masa awal kehidupannya. Hal itu menyebabkan terjadinya kematian selama penelitian. Disamping itu lobster air tawar yang dijadikan penelitian adalah yang baru berumur 1 hari, sehingga sangat sensitif terhadap perubahan lingkungan. Selain itu sifat kanibal juga muncul pada lobster sehat terhadap lobster yang sedang mengalami ganti kulit.

\section{Laju Pertumbuhan Sesaat (Spesific Growth Rate / SGR)}

Parameter utama kedua yang diukur dalam penelitian ini adalah laju pertumbuhan sesaat (SGR) larva lobster air tawar (Cherax quadricarinatus). Laju pertumbuhan sesaat merupakan persentase berat rata-rata individu perhari. Berdasarkan data berat rata- rata larva lobster setiap minggunya untuk tiap-tiap perlakuan diperoleh grafik pertumbuhan seperti pada Gambar 2.

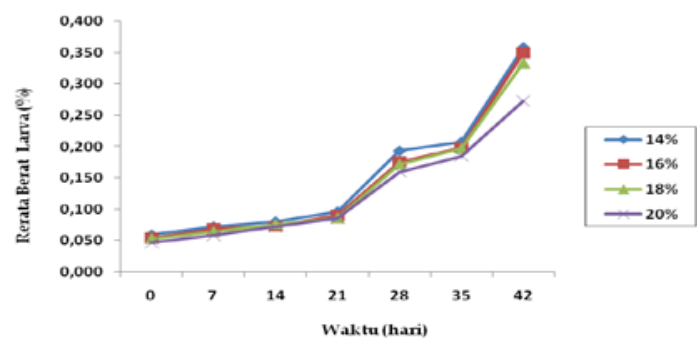

$\begin{array}{rlr}\text { Gambar } & \begin{array}{l}\text { 2.. Grafik } \\ \text { pertambahan }\end{array} & \begin{array}{r}\text { rerata } \\ \text { berat }\end{array} \\ \text { individu larva lobster air } & \text { tawar } & \text { (Cherax } \\ & \text { quadricarinatus) } & \text { selama } \\ \text { penelitian } & \end{array}$

Pada Gambar 2 terlihat bahwa rerata pertambahan berat individu larva lobster air tawar tertinggi setelah 42 hari (6 minggu) masa pemeliharaan dicapai pada perlakuan A (14\%) dan rata-rata terendah pada perlakuan D (20\%). Berdasarkan data rerata pertambahan berat individu larva lobster air tawar, kemudian dilakukan penghitungan laju pertumbuhan sesaat, diketahui bahwa perlakuan memberikan pengaruh yang tidak berbeda nyata terhadap laju pertumbuhan sesaat lobster yang diteliti. Hasil yang tidak berbeda nyata disebabkan nilai rata-rata laju pertumbuhan sesaat memiliki sebaran yang sempit, yaitu berkisar antara 4,27 - 4,71. Grafik rata-rata laju pertumbuhan sesaat dapat dilihat pada Gambar 3.

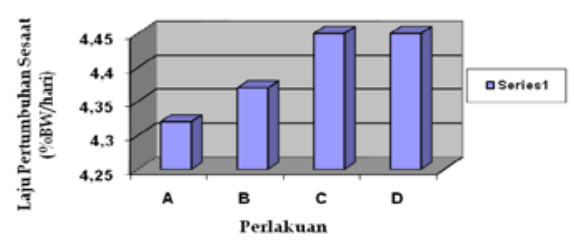




\section{Gambar 3. Grafik laju pertumbuhan sesaat (SGR) larva lobster air tawar (Cherax quadricarinatus) selama penelitian}

Masing-masing perlakuan memberikan laju pertumbuhan yang hampir sama. Pada perlakuan A (14\%) menunjukkan laju pertumbuhan sesaat yang terbaik yaitu 4,46 \% BW/hari. Laju pertumbuhan sesaat semakin menurun dengan meningkatnya dosis pemberian pakan, yang terendah adalah perlakuan D (20\%) sebesar 4,31 \% BW/hari. Menurunnya laju pertumbuhan sesaat disebabkan oleh bertambahnya dosis pemberian pakan alami daphnia. Hal ini berhubungan dengan bertambahnya biomass yang ada dalam wadah perlakuan yang makin padat, sehingga terjadi penurunan oksigen. Dengan demikian laju pertumbuhan juga semakin menurun.

Berat rata-rata larva pada akhir penelitian adalah 0,33 dan nilai rata-rata laju pertumbuhan sesaat (SGR) larva lobster air tawar selama penelitian berada dalam kisaran 4,31 - 4,46 \& BW/hari yang berarti memiliki laju pertumbuhan yang lebih tinggi dibandingkan dengan nilai SGR pada penelitian Jacinto et al. (2003) yaitu 2,97 - 3,64 \% BW/hari dengan berat rata-rata larva adalah 1,08 gram. Menurut Wiyanto dan Hartono (2004), semakin kecil lobster maka laju pertumbuhannya semakin tinggi. Demikian sebaliknya semakin besar lobster maka laju pertumbuhannya semakin menurun.

\section{Rasio Konversi Pakan (Feed Conversion Ratio / FCR)}

Rasio Konversi Pakan (FCR) merupakan perbandingan antara jumlah pakan yang diberikan dengan pertambahan berat badan lobster air tawar selama penelitian (Heinsbroek, 1989). Rasio konversi pakan selama penelitian dapat dilihat pada Gambar 4 berikut ini :

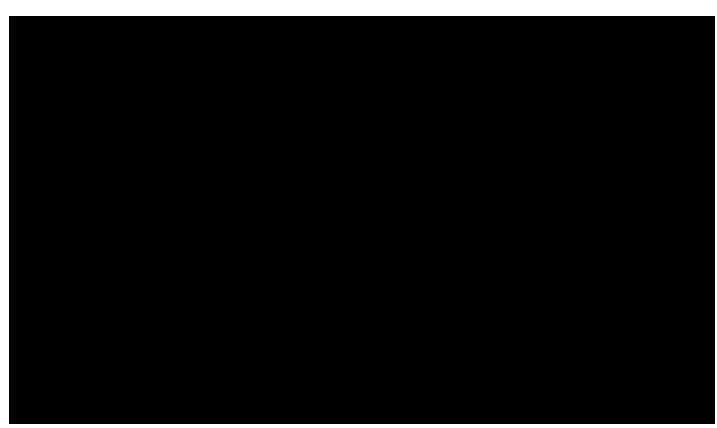

Gambar 4. nilai rasio konversi pakan (FCR) larva lobster air tawar selama penelitian

Berdasarkan sidik ragam diketahui bahwa perlakuan memberikan pengaruh yang berbeda sangat nyata terhadap rasio konversi pakan larva lobster air tawar (Cherax quadricarinatus). Untuk mengetahui perlakuan mana yang terbaik, maka dilanjutkan dengan uji Beda Nyata Terkecil (BNT). Berdasarkan hasil uji BNT diketahui bahwa perlakuan D memberikan hasil yang berbeda sangat nyata terhadap perlakuan $\mathrm{C}$, sedangkan perlakuan $\mathrm{C}$ memberikan hasil yang berbeda sangat nyata terhadap $\mathrm{B}$ dan perlakuan B memberikan hasil yang berbeda sangat nyata terhadap perlakuan A.

Semakin tinggi dosis pakan yang diberikan membuat nilai konversi pakan semakin tinggi. Pada perlakuan A memberikan hasil terbaik dengan nilai konversi pakan yang lebih rendah mengartikan nilai efisiensi yang lebih tinggi dibandingkan perlakuan yang lain. Sedangkan perlakuan D memberikan nilai konversi pakan yang paling tinggi mengartikan nilai efisiensi pakan yang semakin rendah.

Rasio konversi pakan adalah suatu nilai efisiensi penggunaan pakan, 
semakin rendah nilai FCR maka semakin sedikit pakan yang dibutuhkan untuk menghasilkan satu unit berat badan larva lobster air tawar (Buwono, 2000). Semakin rendah nilai FCR maka semakin baik, karena biaya produksi dapat diperkecil sehingga keuntungan yang diperoleh akan semakin besar.

\section{Kesimpulan dan Saran Kesimpulan}

Berdasarkan hasil penelitian dapat disimpulkan bahwa :

- Pemberian pakan alami daphnia sp dengan dosis yang berbeda (14\%; 16\%; 18\% dan 20\%) memberikan pengaruh yang tidak berbeda nyata terhadap kelulushidupan dan pertumbuhan sesaat larva lobster air tawar (Cherax quadricarinatus)

- Tingkat kelulushidupan larva lobster air tawar (Cherax quadricarinatus) relatif cukup tinggi dengan kisaran rata-rata yaitu $86-90 \%$.

- Pemberian pakan alami Daphnia sp dengan dosis yang berbeda memberikan pengaruh yang berbeda sangat nyata terhadap rasio konversi pakan larva lobster air tawar (Cherax quadricarinatus)

- Nilai rata- rata rasio konversi pakan yang terbaik adalah perlakuan A (14\%) yaitu 0,43 dan yang terendah adalah perlakuan D (20\%) sebesar 0,68

- Kualitas air media berdasarkan pengukuran selama penelitian adalah homogen dan masih berada pada kisaran yang layak untuk hidup dan tumbuh larva lobster air tawar (Cherax quadricarinatus) dengan suhu berkisar antara 18,33 - 19,88 ${ }^{\circ} \mathrm{C}$, dan oksigen terlarut (DO) antara 4,73 - 4,84 mg/l, serta derajat keasaman $(\mathrm{pH})$ antara 7,12 - 7,30.

\section{Saran}

- Perlu dilakukan penelitian lanjutan mengenai pemberian pakan alami Daphnia sp dengan menggunakan dosis yang lebih rendah dari $14 \%$.

- Perlu dikembangkan usaha budidaya pakan alami Daphnia sp sebagai bahan pakan alternatif untuk lobster air tawar (Cherax quadricarinatus) karena harganya relatif murah dan mempunyai nilai gizi cukup tinggi sebagai makanan ikan atau lobster air tawar.

\section{Ucapan Terima Kasih}

Ucapan terima kasih disampaikan kepada Dirjen Dikti yang telah membiayai penelitian ini melalui Program Penelitian Dosen Pemula.

DAFTAR PUSTAKA

Amirin. 1990. Menyusun Rencana Penelitian. Rajawali Pers. Jakarta

Anonymous. 2000.

Crayfish. http://www.enchantedl earning.com /cgibin /uncgi/search? Key =crayfish. Akses : April 2007

-----. 2005. Aquaculture of Non Endemic Species-Redclaw Crayfish. http://www.fish.wa.go v.au/docx/mp/mp100/index.php. Akses : Mei 2007

Djajasewaka, H. 1985. Pakan Ikan. CV Yasaguna. Jakarta

Buwono. 2000. Kebutuhan Asam Amino Esensial dalam Ransum Ikan. Kanisius. Yogjakarta

Heinsbroek, LTW. 1989. Growth and Feeding of Fish. Nuffic / Unibraw / Luw/Fish. Unibraw. Malang 
Iskandar. 2003. Budidaya Lobster Air Tawar. Agromedia Pustaka. Jakarta

Jacinto, EC. 2003. Effect of Dietary Protein Level on Growth and Survival of Juvenile Freshwater Crayfish Cherax quadricarinatus. Aquaculture Nutrition. Volume 9

Mujiman, A. 2000. Makanan Ikan. Penebar Swadaya. Jakarta.

Murtidjo, BA. 2001. Pedoman Meramu Pakan Ikan. Penerbit Kanisius. Yogyakarta
Patasik, S. 2004. Pembenihan Lobster Air Tawar Lokal Papua. Penebar Swadaya. Jakarta.

Surachmad, W. 1989. Pengantar Penelitian Ilmiah Dasar. Metode dan Teknik Edisi VII. Tarsito. Bandung

Wiyanto, RH dan Hartono, R. 2003. Lobster Air Tawar Pembenihan dan Pembesaran. Penebar Swadaya. Jakarta

Wiyanto. RH dan Hartono, R. 2004. Merawat Lobster Hias di Aquarium. Penebar Swadaya. Jakarta 